\title{
Effects of streptozotocin- and alloxan-induced diabetes mellitus on mouse follicular and early embryo development
}

M. P. Diamond, K. H. Moley†, A. Pellicer $\ddagger$, W. K. Vaughn* and A. H. DeCherney

Division of Reproductive Endocrinology, Department of Obstetrics and Gynecology, Yale University School of Medicine, New Haven, CT 06510, USA, and *United Network for Organ Sharing, Richmond, VA 23228, USA

\begin{abstract}
Summary. Mice were made diabetic by intraperitoneal injection of streptozotocin or alloxan. Germinal vesicle breakdown in the ovarian follicles at $8 \mathrm{~h}$ after hCG in control animals $(57 \%)$ was significantly greater than in streptozotocin- $(24 \%)$ and alloxan$(42 \%)$ diabetic animals $(P<0.001)$. This delay in oocyte maturation was reversible by in-vivo insulin administration to diabetic mice. A developmental delay was also found for embryos recovered from diabetic mice. This developmental delay extended into the $72 \mathrm{~h}$ in-vitro cultures. Compared to control embryos, those from alloxan- and streptozotocin-treated mice demonstrated marked impairment in development as assessed by (1) distribution of developmental cell stages at each observation period and (2) rates of development which increasingly diverged at each observation period.

In diabetic mice treated with insulin in vivo, the percentage of 2-cell embryos recovered increased. Furthermore, in streptozotocin- and alloxan-animals treated with insulin, the rate of in-vitro development of embryos, as well as their developmental stage distribution improved. We therefore suggest that uncontrolled diabetes mellitus, as well as contributing to the development of congenital malformations, may deleteriously affect reproductive performance both before fertilization and at the very earliest gestational stages.
\end{abstract}

Keywords: diabetes mellitus; zygote; oocyte; alloxan; streptozotocin; mouse

\section{Introduction}

It is well established that the fetus of the mother with poorly controlled diabetes mellitus is at increased risk for neonatal morbidity and mortality (Diamond et al., 1987). With the institution of meticulous diabetic control during pregnancy, the risk of these complications can be significantly reduced. An exception is the increased incidence of congenital malformations, which can only be lowered by institution of precise metabolic control before organogenesis (Fuhrmann et al., 1983).

Less recognized, and less accepted, are the deleterious effects of diabetes on reproductive performance at earlier stages of pregnancy. Several reports have suggested a direct correlation between the degree of metabolic control and the occurrence of spontaneous miscarriages in diabetic women (Miodovnik et al., 1984, 1985, 1986), but such relationships remain controversial (Pedersen, 1977; Kitzmiller et al., 1978; Kalter, 1985). Additionally, in women (Parsons et al., 1926) and other animals (Chieri et al., 1969), poor metabolic control is associated with anovulation, while

$\dagger$ Present address: Department of Obstetrics and Gynecology, Washington University School of Medicine, St Louis, MO 63I10, USA.

$\ddagger$ Present address: Department of Obstetrics and Gynecology, Hospital Clinico Universitario, Avda Blasco Ibanez, 17 Valencia 46010 , Spain. 
insulin therapy restores ovarian cyclicity. While a hypothalamic-pituitary aetiology of this anovulation has been suggested by the work of Djursing et al. (1982a,b, 1983) and Distiller et al. (1975), Liu et al. (1972) suggested an ovarian contribution.

To elucidate the mechanism by which diabetes mellitus impairs reproductive performance, this report examines the effect of diabetes on the processes of ovarian follicular development, oocyte maturation, and early growth and development of mouse embryos.

\section{Materials and Methods}

The study was conducted using female mice of the $\mathrm{B}_{6} \mathrm{C}_{3} \mathrm{~F}_{1}$ strain, $8-10$ weeks of age (Charles River Breeding Laboratories, Inc., Wilmington, MA, USA). Mice were given free access to food and water, and maintained in a $12 \mathrm{~h}$ light/ dark cycle (lights on at 06:00 h). In all mice, superovulation was achieved with a subcutaneous injection of 5 i.u. PMSG/animal (Gestyl: Organon, OSS, The Netherlands), followed 48 h later by 5 i.u. hCG (Pregnyl: Organon). In those studies examining embryo development, female mice were mated with males of proven fertility overnight after hCG injection. Mating was confirmed by identification of a vaginal plug.

Creation of the diabetic state. A diabetic state was induced by two methods, intraperitoneal injection of streptozotocin, $330 \mathrm{mg} / \mathrm{kg}$ (Sigma, St Louis, MO, USA), and intraperitoneal injection of alloxan, $300 \mathrm{mg} / \mathrm{kg}$ (Sigma), based on a modification of the report of Rerup \& Tarding (1969). Verification of the induction of diabetes mellitus in each group was by serum glucose measurement of $\geq 180 \mathrm{mg} / \mathrm{dl}$ by Chemstrip (Becton-Dickinson, Rutherford, NJ, USA) and/or by measurement of serum glucose concentrations on a Beckman Glucose Analyzer II (Beckman Instruments Inc., Fullerton, CA, USA). (Chemstrips measure blood glucose concentrations from $<20 \mathrm{mg} / \mathrm{dl}$ to $>800 \mathrm{mg} / \mathrm{dl}$ ). Subsequently, monitoring of diabetic metabolic control employed the same methods. Blood glucose determinations were also made at the time of killing of all mice. At least 4 days intervened between administration of streptozotocin or alloxan and the PMSG injection. Mice were demonstrated to be diabetic by blood glucose determinations of $\geq 180 \mathrm{mg} / \mathrm{dl}$ before initiating PMSG injections. The blood glucose concentration in non-diabetic mice at the time of oocyte/embryo recovery in all groups ranged from 40 to $120 \mathrm{mg} / \mathrm{dl}$.

As indicated, ultralente insulin (Lilly, Indianapolis, IN, USA) was injected once daily subcutaneously at a dose of $110 \mathrm{U} / \mathrm{kg} / \mathrm{day}(\sim 1.8 \mathrm{U} /$ day $)$. Twice daily insulin administration consisted of injection of $\sim 2.0 \mathrm{U} /$ day, in divided doses of $\sim 1$ U ultralente insulin. Insulin was administered for 3 days before PMSG administration. Mice were demonstrated to be diabetic by blood sugar determinations of $\geq 240 \mathrm{mg} / \mathrm{dl}$ before initiating insulin injections. Separate control groups were utilized when studies of alloxan- and streptozotocin-treated mice were not performed concomitantly.

Oocyte maturation. Oocyte maturation in vitro, as assessed by germinal vesicle breakdown (GVBD), was determined in mice receiving PMSG and hCG. Mice were killed by cervical dislocation $6 \mathrm{~h}$ after hCG administration. The ovaries were dissected free and placed in Ham's F-10 medium (Flow Labs, Inc., McLean, VA, USA). During examination under a dissecting microscope, large preovulatory follicles were punctured with a stainless-steel needle and the oocytes were collected in Ham's F-10 medium at room temperature $\left(21^{\circ} \mathrm{C}\right)$. Each oocyte-cumulus complex was denuded of the corona cumulus investments by repeated passage through a narrow-bore drawn glass pipette and by placement in $0.1 \%$ hyaluronidase (Sigma) in Ham's F-10 medium. Denuded oocytes were then visualized by Nomarski optics, and oocytes that retained a germinal vesicle and/or nucleolus were considered to show inhibition of maturation. Observation was performed by an individual unaware of the derivation of the oocytes. Oocyte maturation was expressed as percentage GVBD.

Assessment of ovarian response to exogenous PMSG and hCG was performed in mice killed $\sim 24 \mathrm{~h}$ after hCG administration. Animals were killed by cervical dislocation, and the oviducts isolated. Using a dissecting microscope (Wild, Heerbrugg, Switzerland), the oviducts were examined to identify the site of tubal distensions indicating the oocyte-cumulus complexes. This site was incised with a fine instrument and the extruded oocyte-cumulus complexes were collected. The cumulus was dissociated from the oocytes by using $0 \cdot 1 \%$ hyaluronidase (Sigma) and the number of oocytes in each group was counted individually.

Development of zygotes. To assess growth of zygotes in vitro, animals were killed by cervical dislocation $48 \mathrm{~h}$ after hCG administration and mating. Zygotes were flushed from the oviducts by using a dissecting microscope and a blunted 30-gauge needle (Becton-Dickinson, Rutherford, NJ, USA). The numbers of 1-cell and 2-cell structures were counted. Since the 1-cell structures could include both unfertilized oocytes and zygotes which could not be morphologically differentiated, comparison was made of the percentage of 2-cell zygotes in the total number of 1-cell and 2-cell structures.

Two-cell zygotes were placed in $1 \mathrm{ml} \mathrm{Ham}$ 's F-10 medium with $0.1 \%$ bovine serum albumin (Sigma, fraction V) in groups of $15-30 \mathrm{embryos} / \mathrm{dish}$. The zygotes were incubated for $72 \mathrm{~h}$ at $37^{\circ} \mathrm{C}$ in an atmosphere of $5 \% \mathrm{CO}_{2}, 5 \% \mathrm{O}_{2}$ and $90 \% \mathrm{~N}_{2}$. Development was evaluated every $24 \mathrm{~h}$ for a total span of $72 \mathrm{~h}$. One-cell structures were collected and cultured similarly but separately in $1 \mathrm{ml} \mathrm{Ham}$ 's F-10 medium with $0.1 \%$ bovine serum albumin.

The number of blastomeres, as well as signs of degeneration or abnormalities as manifested by the swelling of the cell or the appearance of intracellular vacuoles were observed at each time period. The observer was unaware of the 
group assignment of the cultures being viewed at 24,48 and $72 \mathrm{~h}$. The embryos were assigned to the following developmental stages: degenerated; $2,3,4,5,6,7$ or 8 blastomeres; morula; blastocyst; and expanded blastocyst. Some zygotes appeared to be composed of multiple variably sized and poorly organized groupings of blastomeres. Such embryos were called 'disorganized'. For the purposes of statistical analysis, such multicellular embryos were considered to be morulae.

The streptozotocin-diabetic mice treated with insulin once or twice daily were further subdivided for some comparisons into subgroups with 'better' or 'poorer' metabolic control. This was done based on the serum blood sugar concentration at the time of death, and embryos were identified as being derived from mice with blood sugar values below or above $180 \mathrm{mg} / \mathrm{dl}$ respectively. While this was only a single value, and was obtained in animals which had had free access to food, we believe it may serve as a gross guide of the state of metabolic regulation.

Statistical analysis. Statistical analysis was performed by Student's $t$ test, $\chi^{2}$ analysis and by two-way analysis of variance of the averaged rank of sums in a randomized block design as appropriate. The latter analysis allowed comparison of zygote development on each day of observation as well as comparison of the rate of development between the respective groups. The calculation is performed by assigning each stage of zygote development a rank. For each time within each treatment group the product of the number of cells and the appropriate rank number is formed and summed for each time. This sum of products is then divided by the number of zygotes to provide an average rank sum. This measure increases as the embryos develop more maturity. The two-way analysis of variance allows comparison of treatment groups, times, and the interaction of groups and time. The treatment groups demonstrate an interaction when maturation occurs at different rates in the two treatments.

For all statistical analysis, control group numbers were those from non-diabetic mice treated simultaneously. Since streptozotocin- and alloxan-diabetic mice were usually studied separately, this resulted in separate control groups. Results are expressed as mean \pm s.e.m. Statistical significance was defined as $P<0.05$.

\section{Results}

\section{Follicular recruitment and oocyte maturation}

As assessed by the number of oocyte-cumulus complexes, there was no difference in ovarian response to PMSG/hCG stimulation in non-diabetic control $(\mathrm{N}=18 ; 38 \cdot 3 \pm 11.8 / \mathrm{mouse})$ and streptozotocin-diabetic ( $\mathrm{N}=19 ; 35.4 \pm 9 \cdot 9$ /mouse) mice. The number of oocyte cumulus complexes per alloxan-treated mouse $(\mathrm{N}=14 ; 27 \cdot 1 \pm 12 \cdot 1)$ was insignificantly reduced compared to control mice $(\mathrm{N}=16 ; 35.1 \pm 15 \cdot 4)$ but this treatment repeatedly produced moderate to extensive peritoneal adhesions which may have reduced tubal ovum pickup.

Compared to controls, the rate of GVBD was significantly less in oocytes collected from streptozotocin- and alloxan-diabetic mice, indicating a delay in oocyte maturation in these groups (Table 1). Insulin therapy to streptozotocin- and alloxan-diabetic mice resulted in a correction of maturational lag in oocytes collected from diabetic mice.

Table 1. Oocyte maturation as assessed by germinal vesicle breakdown (GVBD) in oocytes collected from control, streptozotocin-diabetic and alloxandiabetic mice

\begin{tabular}{lccc}
\hline & $\begin{array}{c}\text { Blood } \\
\text { glucose } \\
(\mathrm{mg} / \mathrm{dl})\end{array}$ & $\begin{array}{c}\text { Total } \\
\text { no. of } \\
\text { oocytes }\end{array}$ & $\begin{array}{c}\% \\
\text { GVBD }\end{array}$ \\
\hline $\begin{array}{c}\text { No insulin therapy } \\
\text { Control }\end{array}$ & $40-120$ & 98 & 57 \\
$\begin{array}{c}\text { Streptozotocin } \\
\text { diabetic }\end{array}$ & $\geq 180$ & 97 & $24^{*}$ \\
$\quad \begin{array}{c}\text { Alloxan diabetic } \\
\geq 180\end{array}$ & 180 & $42^{*}$ \\
$\begin{array}{c}\text { Insulin once daily } \\
\text { Control }\end{array}$ & $40-120$ & 62 & 60 \\
$\begin{array}{c}\text { Streptozotocin } \\
\text { diabetic }\end{array}$ & $80-240$ & 43 & 60 \\
Alloxan diabetic & $80-240$ & 60 & 57 \\
\hline
\end{tabular}

${ }^{*} P<0.001$ compared with control value. 


\section{Development at recovery}

Compared to control mice, ova collected from streptozotocin-diabetic and alloxan-diabetic mice demonstrated reduced percentages of 2-cell zygotes (Table 2), and therefore impairment in development. There was a reduction in the number of 2-cell embryos per mouse in the streptozotocin- and alloxan-diabetic groups, although the difference only reached statistical significance in the latter group (streptozotocin vs control, $21.8 \pm 3.4$, and $30.7 \pm 3.3$, NS; alloxan $v s$ control, $13.6 \pm 1.8$ and $23.1 \pm 2.8, P<0.01$ ). Among one-cell structures recovered from streptozotocinand alloxan-diabetic mice and cultured in vitro, $50(40 \%)$ progressed to 2 or more blastomeres during in-vitro culture.

Table 2. Distribution of 1-cell structures and 2-cell zygotes in non-diabetic, streptozotocin-diabetic, and alloxan-diabetic mice killed $48 \mathrm{~h}$ after hCG administration and mating

\begin{tabular}{|c|c|c|c|c|c|}
\hline & \multirow{2}{*}{$\begin{array}{l}\text { Blood } \\
\text { glucose } \\
(\mathrm{mg} / \mathrm{dl})\end{array}$} & \multirow{2}{*}{$\begin{array}{l}\text { No. of } \\
\text { mice }\end{array}$} & \multirow{2}{*}{$\begin{array}{l}\text { No. of } \\
\text { 1-cell } \\
\text { structures }\end{array}$} & \multicolumn{2}{|c|}{$\begin{array}{c}\text { 2-Cell } \\
\text { zygotes }\end{array}$} \\
\hline & & & & No. & $\%$ \\
\hline Non-diabetic & $40-120$ & 21 & 49 & 623 & 93 \\
\hline Streptozotocin diabetic & $\geq 180$ & 18 & 106 & 358 & $77^{*}$ \\
\hline Non-diabetic & $40-120$ & 16 & 45 & 369 & 89 \\
\hline Alloxan diabetic & $\geq 180$ & 17 & 89 & 218 & $71+$ \\
\hline
\end{tabular}

${ }^{*} P<0.001$ compared with non-diabetic control.

$\dagger P<0.001$ compared with non-diabetic control.

\section{Morphology of zygotes from mice with streptozotocin- or alloxan-induced diabetes mellitus}

At $24 \mathrm{~h}$ after recovery, most zygotes from streptozotocin-alloxan-treated mice had a normal appearance and these embryos were morphologically indistinguishable from those of non-diabetic mice. However, $4 \cdot 1 \%$ and $5.4 \%$ of zygotes from streptozotocin- and alloxan-treated mice appeared unusual. Such embryos had multiple blastomeres of various sizes and were without apparent organization as seen in normal morulae. Cellular tissue was not condensed as in degenerated embryos. Some of these 'disorganized' embryos developed into blastocysts.

'Disorganized' morulae were only identified from diabetic mice. Insulin therapy in streptozotocinmice reduced the frequency of these morulae to $1.3 \%$ and $0 \%$ in mice receiving insulin once daily and twice daily respectively. In alloxan-diabetic mice treated with insulin, 'disorganized' morulae were not observed.

\section{Growth of 2-cell zygotes cultured in vitro}

As shown in Figs 1 and 2, zygotes from non-diabetic mice demonstrated significant progression in stages of development at each observation period compared to the other observational periods $(24,48$, and $72 \mathrm{~h}, P<0.0001)$.

\section{Effect of streptozotocin and alloxan diabetics}

In streptozotocin-treated mice, the distribution of zygotes was different at each observation time (Fig. Ia). At $24 \mathrm{~h}, 30 \%$ of zygotes remained at the 2 -cell stage, compared to only $4 \%$ in the control group. At $48 \mathrm{~h}, 30 \%$ of zygotes derived from streptozotocin-treated mice had progressed to the morula or blastocyst stages, compared to $69 \%$ in the controls. At $72 \mathrm{~h}$, the values were $18 \%$ and 


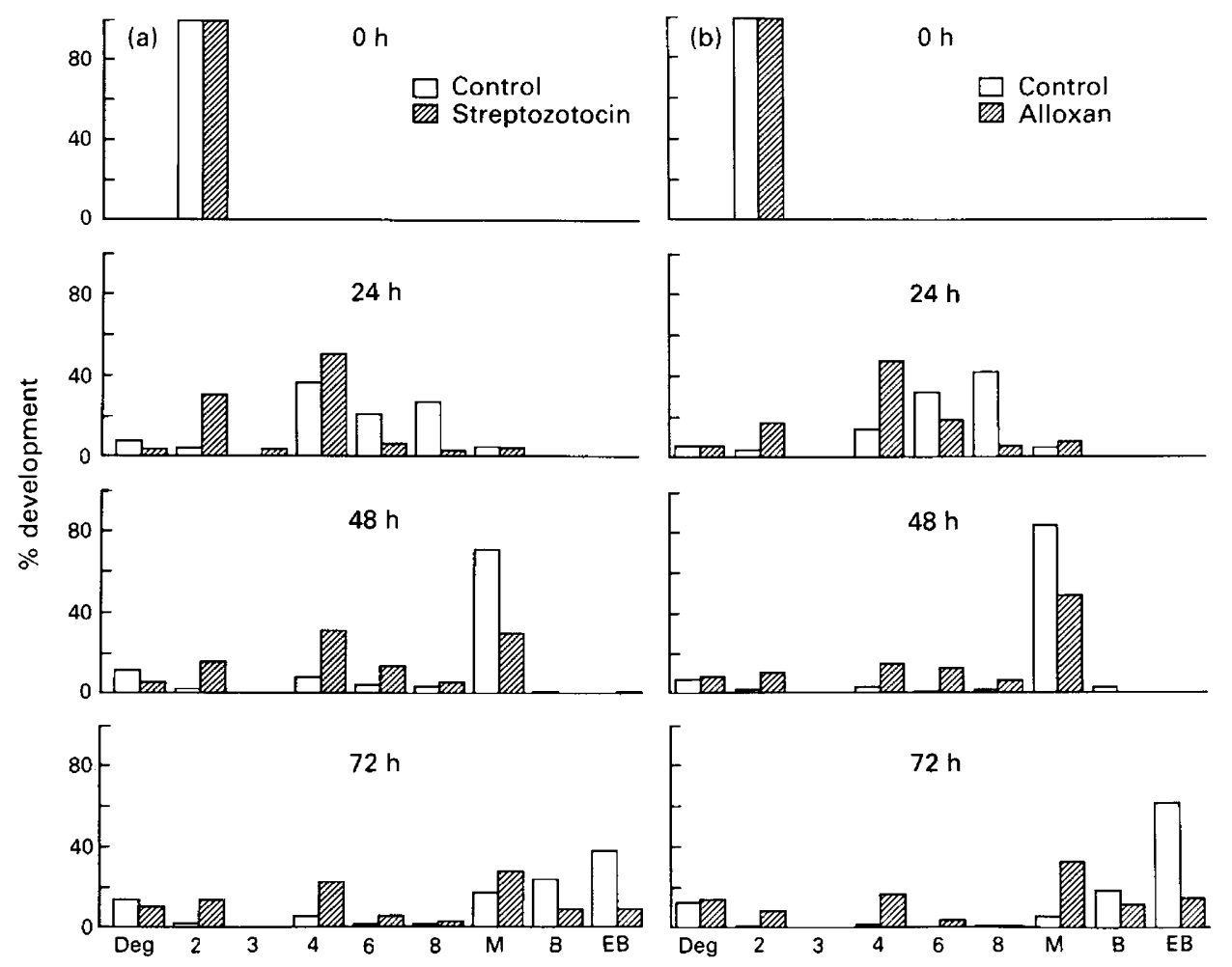

Fig. 1. Stages of development at time of recovery and after culture of embryos recovered from (a) non-diabetic control mice $(n=464)$ and streptozotocin-diabetic mice $(n=387)$, and (b) non-diabetic control mice $(n=252)$ and alloxan-diabetic mice $(n=224)$. Embryo development was graded as degenerated (Deg), 2-cell (2), 3-cell (3), 4-cell (4), 6-cell (6), 8-cell (8), morula (M), blastocyst (B), and expanded blastocyst (EB).

$60 \%$ for development to the blastocyst stage by zygotes from streptozotocin-treated and control mice, respectively. The rate of development of zygotes in the streptozotocin group compared to controls was also significantly reduced $(P<0.0001)$. The difference continued to increase at each period of observation $(P<0.05)$.

Similar findings were obtained for the alloxan-diabetic embryos (Fig. 1b). At each observation period, a significant retardation in progression of development was noted as compared to control embryos $(P<0.001$ at all time periods). Also, the rate of development was significantly reduced in the alloxan-treated group $(P<0.0001)$; the difference continued to increase at each successive period of observation $(P<0.02)$.

\section{Insulin therapy in streptozotocin and alloxan diabetes}

When mice made diabetic with streptozotocin or alloxan were treated once daily with insulin, there was no difference in the numbers of 2-cell zygotes per animal in the treatment or their respectjve control groups. As shown in Table 3, among alloxan-diabetic mice, administration of insulin increased the percentage of 2-cell embryos by $10 \%$ such that no significant difference in the percentage of two-blastomere embryos persisted (as had been present in embryos from alloxan-diabetic mice not treated with insulin). There was a trend toward a greater number of two-blastomere embryos per animal (as compared to one-cell structures) in the streptozotocin group treated with 

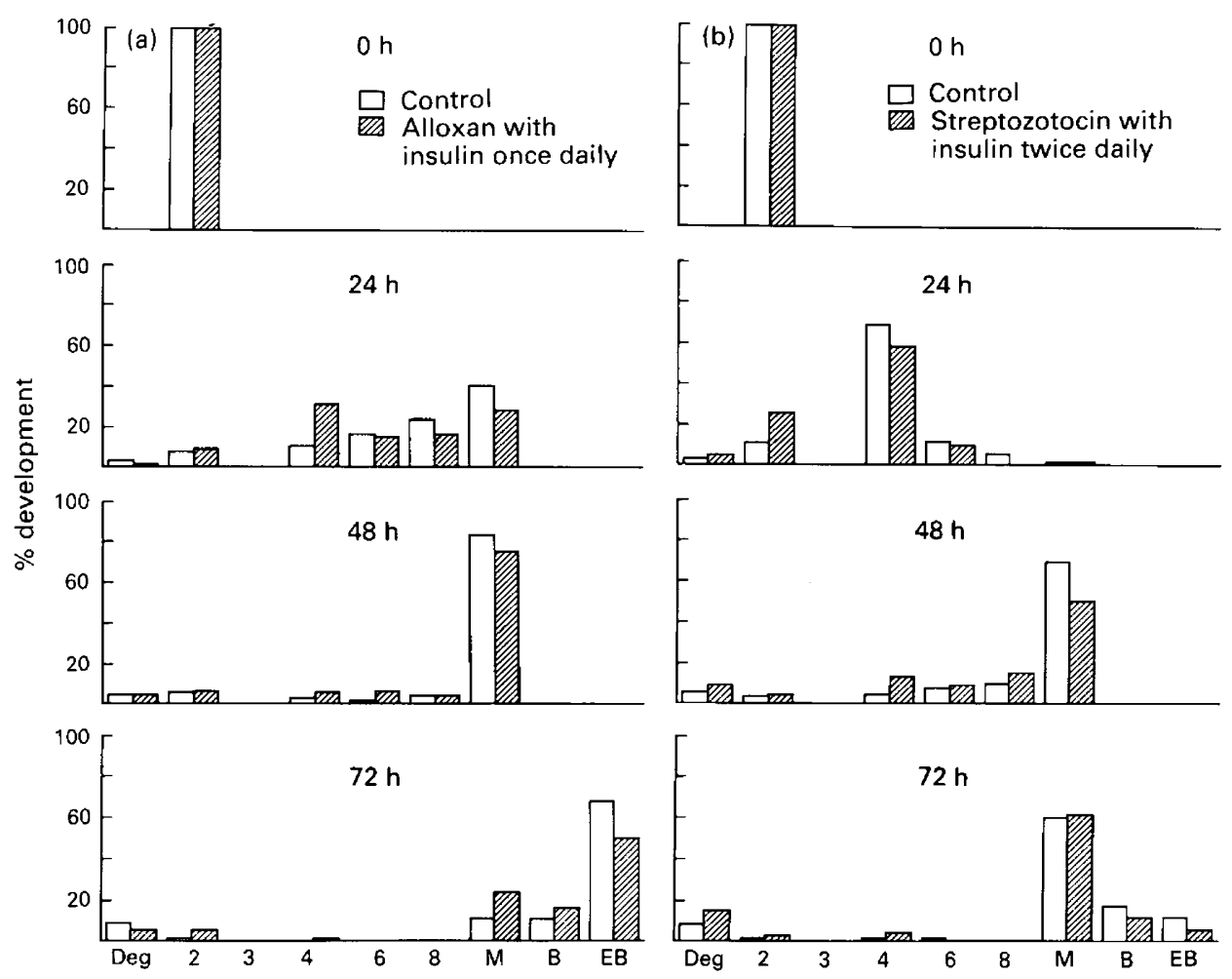

Fig. 2. Stages of development at time of recovery and after culture of embryos recovered from (a) non-diabetic control mice $(n=81)$ and alloxan-diabetic mice treated with insulin once daily $(n=82)$ and (b) non-diabetic control mice $(n=306)$ and streptozotocin-diabetic mice treated with insulin twice daily $(n=308)$. Embryo development was graded as degenerated (Deg), 2cell (2), 3-cell (3), 4-cell (4), 6-cell (6), 8-cell (8), morula (M), blastocyst (B), and expanded blastocyst (EB).

insulin, as compared to those mice receiving streptozotocin alone although a significant difference $(P<0.05)$ persisted. Consistent with this trend is the greater 2 -cell distribution in mice with better blood glucose control (blood glucose $\leqslant 180 \mathrm{mg} / \mathrm{dl}$ at the time of recovery (Table 3)).

Comparison of distribution of 2-cell embryos between non-diabetic $(n=403)$ and streptozotocin + insulin $(n=398)$ groups demonstrated a continued difference at 24,48 and $72 \mathrm{~h}(P<0 \cdot 001)$ (data not shown). Rate of development of embryos in these two groups also differed $(P<0.0001)$. Among alloxan + insulin-treated mice (Fig. 2a), the rate of development also remained significantly different $(P<0.05)$. In neither diabetic group did the difference in rate of development (as compared to controls) significantly decrease further over the ensuing period of observation. The difference between control and diabetic groups could therefore be attributed to the change observed at the $24 \mathrm{~h}$ observation period.

Comparison of development in treatment groups with alloxan + insulin (Fig. 2a) and alloxan alone (Fig. 1b) demonstrates differences in distribution at $24 \mathrm{~h}(P<0.001), 48 \mathrm{~h}(P<0.003)$ and $72 \mathrm{~h}(P<0.001)$, and in the rate of development $(P<0.0001)$, such that embryos derived from mice treated with insulin manifested more advanced maturational development. Furthermore, the difference in rate of development of zygotes in these two treatment groups continued to increase over the observation period $(P<0.05)$. 
Table 3. Distribution of 1-cell structures and 2-cell embryos in non-diabetic mice and in streptozotocin-diabetic or alloxan-diabetic mice treated with insulin, and killed $48 \mathrm{~h}$ after hCG administration and mating

\begin{tabular}{|c|c|c|c|c|c|}
\hline & \multirow{2}{*}{$\begin{array}{l}\text { Blood } \\
\text { glucose } \\
(\mathrm{mg} / \mathrm{dl})\end{array}$} & \multirow{2}{*}{$\begin{array}{l}\text { No. of } \\
\text { animals }\end{array}$} & \multirow{2}{*}{$\begin{array}{l}\text { No. of } \\
\text { 1-cell } \\
\text { No. }\end{array}$} & \multicolumn{2}{|c|}{$\begin{array}{l}\text { 2-Cell } \\
\text { zygotes }\end{array}$} \\
\hline & & & & No. & $\%$ \\
\hline Non-diabetic*† & $40-120$ & 28 & 75 & 575 & 88 \\
\hline $\begin{array}{l}\text { Streptozotocin diabetic }+ \text { in } \\
\text { Total* } \\
\text { Poorer control } \\
\text { Better control } \dagger\end{array}$ & $\begin{array}{r}80-240 \\
\geq 180 \\
<180\end{array}$ & $\begin{array}{r}25 \\
9 \\
16\end{array}$ & $\begin{array}{r}105 \\
43 \\
62\end{array}$ & $\begin{array}{l}430 \\
108 \\
322\end{array}$ & $\begin{array}{l}80 \\
72 \\
84\end{array}$ \\
\hline $\begin{array}{l}\text { Non-diabetic } \ddagger \\
\text { Alloxan diabetic }+ \text { insulin } \ddagger\end{array}$ & $\begin{array}{l}40-120 \\
80-240\end{array}$ & $\begin{array}{r}11 \\
6\end{array}$ & $\begin{array}{l}39 \\
19\end{array}$ & $\begin{array}{r}214 \\
80\end{array}$ & $\begin{array}{l}85 \\
81\end{array}$ \\
\hline
\end{tabular}

${ }^{*} P<0.001$ vs total streptozotocin diabetic.

$\dagger P<0.05$ vs better control, streptozotocin diabetic.

$\ddagger$ NS $v$ alloxan diabetic.

\section{Effect of twice daily insulin therapy}

To assess whether the improvements in the streptozotocin- and alloxan-treated groups induced by once daily insulin administration could be further enhanced, a more frequent course of insulin administration was given to a third group of streptozotocin-diabetic mice. Comparison of the percentage of 2-cell embryos with non-diabetic controls at the time of recovery revealed no difference (Table 4). Zygotes from mice treated with streptozotocin + insulin and with blood sugar values of $\leqslant 120 \mathrm{mg} / \mathrm{dl}$ at the time of death were not significantly different in their distribution at $72 \mathrm{~h}$ or in the rate of development compared with those from non-diabetic mice (Fig. 2b). Comparison of the rate of development of 2-cell embryos recovered from mice treated with streptozotocin without insulin, streptozotocin with insulin once daily, and streptozotocin with insulin twice daily demonstrated a significantly faster rate of development with increasing insulin treatment $(P<0.05)$. This represented primarily a difference in development in the groups without insulin, and with insulin twice daily $(P<0.05)$.

Table 4. Distribution of 1-cell structures and 2-cell embryos in non-diabetic mice and in streptozotocin-diabetic mice treated with insulin twice daily, and killed $48 \mathrm{~h}$ after $\mathrm{hCG}$ administration and mating

\begin{tabular}{|c|c|c|c|c|c|c|}
\hline & \multirow{2}{*}{$\begin{array}{l}\text { Blood } \\
\text { glucose } \\
(\mathrm{mg} / \mathrm{dl})\end{array}$} & \multirow{2}{*}{$\begin{array}{c}\text { No. of } \\
\text { animals }\end{array}$} & \multicolumn{2}{|c|}{$\begin{array}{c}\text { 1-Cell } \\
\text { structures }\end{array}$} & \multicolumn{2}{|c|}{$\begin{array}{c}2 \text {-Cell } \\
\text { zygotes }\end{array}$} \\
\hline & & & No. & $\%$ & No. & $\%$ \\
\hline Non-diabetic & $40-120$ & 16 & 81 & 17 & 387 & 83 \\
\hline \multicolumn{7}{|c|}{ Streptozotocin diabetics } \\
\hline Total & $60-240$ & 14 & 91 & 22 & 323 & 78 \\
\hline Poorer control & $\geq 180$ & 3 & 30 & 23 & 101 & 77 \\
\hline Better control & $<180$ & 11 & 61 & 22 & 222 & 78 \\
\hline
\end{tabular}

\section{Discussion}

In the diabetic female, the aetiology of anovulation, and its resultant amenorrhoea, has been variably attributed to hypothalamic-pituitary and to ovarian factors. With regard to the former, diabetic women have low concentrations of luteinizing hormone and prolactin compared to non- 
diabetic controls (Djursing et al., 1982b, 1983). Additionally, dynamic evaluation of luteinizing hormone, follicle-stimulating hormone and prolactin show diminished response compared to nondiabetic controls (Distiller et al., 1975; Djursing et al., 1983). An ovarian contribution to the amenorrhoea/anovulation seen in females with diabetes mellitus has been implicated from a variety of studies, including demonstrations of ovarian atrophy (Lawrence \& Cantalopoulos, 1960; Liu et al., 1972; Garris et al., 1982), impaired folliculogenesis (Garis et al., 1982, 1984), alterations in ovulation pattern (Chieri et al., 1969; Vomachka \& Johnson, 1982), and impaired steroidogenesis (Barbieri et al., 1983).

In the current study, PMSG and hCG were administered to mice, thus bypassing to some extent the hypothalamic-pituitary hormonal regulation of folliculogenesis seen in the normal cycle. Comparison of the number of oocytes recovered showed no difference between non-diabetic and diabetic groups. In the diabetic state, therefore, the ovary responds normally to exogenous gonadotrophin administration, at least with regard to the number of follicles which develop as assessed by the number of oocytes recovered. These results concur with the observations of Funaki \& Mikamo (1983) for the Chinese hamster, but vary from the reports of Chieri et al. (1969) and Yamamoto et al. (1971) for mice. These apparent differences may reflect species variation, may be due to stimulation with exogenous gonadotrophins in our study and spontaneous cycles in both the other papers, or variations in the severity of the diabetic state. Alternatively, this discrepancy may reflect the inability of some of the oocytes recovered in our study to go on to later stages of embryonic development. This last hypothesis agrees with our examination of GVBD in oocytes derived from diabetic mice not treated with insulin which demonstrated a delay in resumption of meiosis $I$, and thus a retardation in oocyte maturation. These findings are also consistent with intrafollicular 'overripeness' which has been implicated in preventing fertilization of severely affected oocytes, and in causing developmental delay and chromosomal anomalies in moderately affected eggs (Mikamo, 1968a; Mikamo \& Iffy, 1974).

Comparison of embryos recovered $48 \mathrm{~h}$ after $\mathrm{hCG}$ administration in the non-diabetic mice with those from streptozotocin- or alloxan-diabetic mice demonstrated a difference in the percentage of 2-cell zygotes. Since observation of the number of cells constitutes a static examination of a progressing dynamic process, such evaluations are unable to characterize the process fully. Nevertheless, they allow documentation of a retardation of development of embryos derived from diabetic mothers, which could be the consequence of delayed oocyte maturation, impairment of oocyte fertilization, and retardation of zygote development and cleavage.

The mechanism of this delay in development is not evident. It may reflect a direct deleterious effect in vivo due to altered levels of glucose, amino acids, lactate, or fatty acids, or an indirect effect on DNA, RNA or protein synthesis. Alternatively, the impairment may reflect insulin deficiency in the maternal oviducal milieu. In mouse embryos, insulin binding has been identified beginning at the 8-cell stage (Rosenblum et al., 1986). Also, insulin stimulates growth and development of Day-2 chick embryos in a dose-dependent fashion (de Pablo et al., 1982), while insulin antibodies cause growth retardation and embryo death in the same chick embryo model (de Pablo et al., 1985). Applicability of these findings to other species will have to be established, as no delay in in-vivo maturational development in embryos from diabetic Chinese hamsters has been noted (Funaki \& Mikamo, 1983). However, failure to note a developmental delay in that report may have been due to a less severe state of diabetes mellitus, and thus less severe metabolic derangements. This growth retardation of embryos in the present study is consistent with the in-vivo findings of Pedersen \& Molsted-Pederson $(1979,1981)$ in which diabetic women were found by ultrasound to have smaller fetuses in the 7 th to 14 th week of pregnancy as assessed by crown-to-rump length and mean birth weight measurements.

Comparing in-vitro development of embryos in the non-diabetic control group with that in streptozotocin- or alloxan-treated mice, the diabetic state caused an impairment in the rate of development of mouse embryos. This effect of diabetes was increasingly manifested in both diabetic groups, despite culturing all the embryos under the same in-vitro conditions. 
During the development of embryos from diabetic mice, 'disorganized' morulae were observed in which the blastomeres were of different sizes, and were without the normal relationships with each other. Some of these morulae progressed to the small blastocyst stage. The aetiology of these morulae is not known, but it is tempting to speculate that such 'disorganized' embryos may have reduced viability, and as such could lead to biochemical pregnancies, spontaneous abortions, and/ or congenital malformations. These morulae may represent aberrant morphological development of chromosomally normal embryos, or they may represent an abnormal chromosomal pattern. Such chromosomal abnormalities have been reported to be at increased frequency in embryos in diabetic mice (Yamamoto et al., 1971) and in fertilized oocytes that had been subjected to moderate degrees of intrafollicular overripening (Mikamo, 1968b). Furthermore, Mikamo (1968a) reported irregularities in early morphogenesis such as abnormal cleavage patterns in fertilized Xenopus eggs derived from overripe follicles which had exhibited abnormal chromosomal characteristics.

Treatment of streptozotocin- or alloxan-diabetic mice with once daily insulin resulted in correction of the oocyte maturational lag as assessed by GVBD, and partial amelioration of the lag in development noted for untreated diabetic mice. Additionally, when streptozotocian-diabetic mice were treated with insulin twice daily to improve metabolic control further, there was further improvement in both the stage of maturation observed at the time of embryo recovery, and of subsequent in-vitro growth. Consequently, in addition to concern about metabolic control during the period of organogenesis in order to prevent the development of congenital malformations (Watanabe \& Ingalls, 1963; Horii et al., 1966; Cockroft \& Coppola, 1977; Deuchar, 1977; Sadler, 1980; Horton \& Sadler, 1983; Freinkel et al., 1984; Reece et al., 1985; Pinter et al., 1986), and during later stages of pregnancy to prevent stillbirths, hyaline membrane disease, macrosomia, etc. (Diamond et al., 1987), it appears that institution of strict metabolic control during the earliest periods after fertilization is needed to preserve normal development. The consequences of failure to achieve this metabolic state are observable in vitro; the in-vivo correlates remain to be established, but may cause the early pregnancy losses described by Miodovnik et al. $(1984,1985,1986)$.

We thank Harold R. Behrman, Ph.D. and Robert S. Sherwin, M.D. for assistance in preparation of this manuscript.

\section{References}

Barbieri, R.L., Makris, A. \& Ryan, K.J. (1983) Effects of insulin on steroidogenesis in cultured porcine ovarian theca. Fert. Steril. 40, 237-241

Chieri, R.A., Pivetta, O.H. \& Foglia, V.G. (1969) Altered ovulation pattern in experimental diabetes. Fert. Steril. 20, 661-666.

Cockroft, D.L. \& Coppola, P.T. (1977) Teratogenic effects of excess glucose on headfold rat embryos in culture. Teratology 16, 141-146.

de Pablo, F., Roth, J., Hernandez, E. \& Pruss, R.M. (1982) Insulin is present in chicken eggs and early chick embryos. Endocrinology 111, 1909-1916.

de Pablo, F., Girbau, M., Gomez, J.A., Hernandez, E. \& Roth, J. (1985) Insulin antibodies retard and insulin accelerates growth and differentiation in early embryos. Diabetes 34, 1063-1067.

Deuchar, E.M. (1977) Embryonic malformations in rats resulting from maternal diabetes: preliminary observations. J. Embryol. exp. Morphol. 41, 93-99.

Diamond, M.P., Salyer, S.L., Vaughn, W.K., Cotton, R. \& Boehm, F.H. (1987) Reassessment of White's classification and Pedersen's prognostically bad signs of diabetic pregnancies in insulin-dependent diabetic pregnancies. Am. J. Obstet. Gynecol. 156, 599-604.
Distiller, L.A., Sagel, J., Morley, J.E., Jotte, B.I. \& Settel, H.C. (1975) Pituitary responsiveness to luteinizing hormone-releasing hormone in insulindependent diabetes mellitus. Diabetes 24, 378-380.

Djursing, H., Nyholm, H.C., Hagen, C., Carstensen, G. \& Pedersen, L.M. (1982a) Clinical and hormonal characteristics in women with anovulation and insulin-treated diabetes mellitus. Am. J. Obstet. Gynecol. 143, 876-882.

Djursing, H., Nyholm, H.C., Hagen, C. \& MolstedPedersen, L. (1982b) Depressed prolactin levels in diabetic women with anovulation. Acta obstet. gynaec. scand. 61, 403-406.

Djursing, H., Hagen, C., Nyholm, H.C., Curstensen, L. \& Andersen, A.W. (1983) Gonadotropin-releasing hormone and prolactin responses to thyrotropinreleasing hormone and metoclopramide in women with amenorrhea and insulin treated diabetes mellitus. J. clin. Endocr. Metab. 56, 1016-1021.

Freinkel, N., Lewis, N.J., Akazawa, S., Roth, S.I. \& Gorman, L. (1984) The honeybee syndromeimplications of the teratogenicity of mannose in ratembryo culture. N. Engl. J. Med. 310, 223-230.

Fuhrmann, K., Reiher, H., Semmler, K., Fischer, F., 
Fischer, M. \& Glockner, E. (1983) Prevention of congenital malformations in infants of insulin-dependent diabetic mothers. Diabetes Care 6, 219-223.

Funaki, K. \& Mikamo, K. (1983) Developmental-stagedependent teratogenic effects of maternal spontaneous diabetes in the chinese hamster. Diabetes 32 637-643.

Garris, D.R., Smith, C., Davis, D., Diani, A.R. \& Gerritsen, G. (1982) Morphometric analysis of the hypothalamic-ovarian of the ketouric-diabetic chinese hamster: relationship to the reproductive cycle. Diabetologia 23, 275-279.

Garris, D.R., Whitehead, D.S. \& Morgan, C.R. (1984) Effects of alloxan-induced diabetes on corpus luteum function in the pseudopregnant rat. Diabetes 33, 611615.

Horii, N., Watanabe, G. \& Ingalls, T.H. (1966) Experimental diabetes in pregnant mice: prevention of congenital malformations in offspring by insulin. Diabetes 15, 194-204.

Horton, W.E., Jr \& Sadler, T.W. (1983) Effects of maternal diabetes on early embryogenesis: alterations in morphogenesis produced by the ketone body $\beta$ hydroxybutyrate. Diabetes 32, 610 616 .

Kalter, H. (1985) Diabetes and spontaneous abortion. Am. J. Obstet. Gynecol. 154, 603 (Correspondence).

Kitzmiller, J., Cloherty, J., Younger, M., Tabatabaii, A., Rothchild, S., Sosenko, I., Epstein, M., Singh, S. \& Neff, R. (1978) Diabetic pregnancy and perinatal morbidity. Am. J. Obstet. Gynecol. 131, 560-580.

Lawrence, L.A. \& Cantalopoulos, A.N. (1960) Reproductive performance in the alloxan diabetic female rat. Acta endocr., Copenh. 33, 175-184.

Liu, F.T.Y., Lin, H.S. \& Johnson, D.C. (1972) Serum FSH, LH and the ovarian response to exogenous gonadotropins in alloxan diabetic immature female rats. Endocrinology 91, 1172-1179.

Mikamo, K. (1968a) Intrafollicular overripeness and teratologic development. Cytogenetics 7, 212-223.

Mikamo, K. (1968b) Mechanism of non-disjunction of meiotic chromosomes and of degeneration of maturation spindles in eggs affected by intrafollicular overripeness. Experientia 24, 75-78.

Mikamo, K. \& Iffy, L. (1974) Aging of the ovum. Obstet. Gynecol. Annual 3, 47--99.

Miodovnik, M., Lavin, J., Knowles, H., Holroyde, J. \& Stys, S. (1984) Spontaneous abortion among insulindependent diabetic women. Am. J. Obstet. Gynecol. 150, 372-375.

Miodovnik, M., Skillman, C., Holroyde, J.C., Butler, J.B., Wendel, J.S. \& Siddiqi, T.A. (1985) Elevated maternal glycohemoglobin in early pregnancy and spontaneous abortion among insulin-dependent diabetic women. Am. J. Obstet. Gynecol. 153,439-442.
Miodovnik, M., Mimouni, F., Tsang, R.C., Ammar, E., Kaplan, L. \& Siddiqi, T.A. (1986) Glycemic control and spontaneous abortion in insulin-dependent diabetic women. Obstet. Gynecol. 68, 366-369.

Parsons, E., Randall, L.M. \& Wilder, R.M. (1926) Pregnancy and diabetes. Med. Clin. North. Am. 10, 679-691.

Pedersen, J.F. (1977) The Pregnant Diabetic and her Newborn, 2nd edn., p. 97. Williams \& Wilkins, Baitimore.

Pedersen, J.F. \& Molsted-Pedersen, L. (1979) Early growth retardation in diabetic pregnancy. $B r$. med. $J$. $1,18-19$.

Pedersen, J.F. \& Molsted-Pedersen, L. (1981) Early fetal growth delay detected by ultrasound marks increased risk of congenital malformation in diabetic pregnancy. Br. med. J. 283, 269-271.

Pinter, E., Reece, E.A., Leranth, C.Z., Sanyal, M.K., Hobbins, J.C., Mahoney, M.J. \& Naftolin, F. (1986) Yolk sac failure in embryopathy due to hyperglycemia. An ultrastructural analysis of the yolk sac differentiation associated with embryopathy in rat conceptuses under hyperglycemic conditions. Terato$\log y$ 33, 363-375.

Reece, E.A., Pinter, E., Leranth, C.Z., Sanyal, M.K., Hobbins, J.C., Mahoney, M.J. \& Naftolin, F.L. (1985) Ultrastructural analysis of malformations of the embryonic neural axis induced by hyperglycemic conceptus culture. Teratology 32, 363-373.

Rerup, C. \& Tarding, F. (1969) Streptozotocin and alloxan-diabetes in mice. Euro. J. Pharmacol. 7, 89-96.

Rosenblum, I.Y., Mattson, B.A. \& Heyner, S. (1986) Stage-specific insulin binding in mouse preimplantation embryos. Devl Biol. 116, 261-263.

Sadler, T.W. (1980) Effects of maternal diabetes on early embryogenesis II. hyperglycemia-induced exencephaly. Teratology 21, 339-347.

Vomachka, M.S. \& Johnson, D.C. (1982) Ovulation, ovarian $17 \alpha$-hydroxylase activity, and serum concentrations of luteinizing hormone, estradiol and progesterone in immature rats with diabetes mellitus induced by streptozotocin. Proc. Soc. exp. Biol. Med. 171, 207-213.

Watanabe, G. \& Ingalls, T.H. (1963) Congenital malformations in the offspring of alloxan-diabetic mice. Diabetes 12, 66-72.

Yamamoto, M., Endo, A., Watanabe, G. \& Ingalls, T.H. (1971) Chromosomal aneuploidies and polyploidies in embryos of diabetic mice. Archs Environ. Health 22, $468-475$.

Received 24 May 1988 